\title{
Inactive Nurses
}

\author{
An Untapped Recruitment Source
}

\section{ANNA E. BARKER, M.A., M.P.H., and EARL E. STATON, M.A.}

T THE 1963 report of the Surgeon General's Consultant Group on Nursing noted that the shortage of professional nurses critically limits the quantity and quality of medical care and concluded that the supply of nurses is not increasing as fast as the demand (1). The shortage of nurses is particularly serious for mental health facilities, which have an average of only 1 nurse for every 53 beds in contrast to 1 nurse per 3 beds in general hospitals.

According to the American Psychiatric Association (2), in 1962 an average of 18.3 percent of the nurse positions were vacant in the nation's State psychiatric institutions. In Kentucky State mental hospitals, however, 22.6 percent of the registered nurse positions were vacant. Even if these vacancies were filled in Kentucky, the State mental hospitals would have only 1 nurse per 53 beds (3). This ratio, compared with the average of 1 nurse per 5 beds in Kentucky's private mental hospitals or the average of 1 nurse per 17 beds for its Federal mental hospitals, illustrates the dire shortage of nurses in Kentucky State mental hospitals.

The American Nurses' Association has noted that because the number of graduates from nursing schools has remained fairly constant over the past 10 years, the increase in nurse supply may largely be attributed to the return of inactive nurses to the profession. However, an estimated 283,000 professional nurses in the

Mrs. Barker is research statistician and Mr. Staton is executive director of the Kentucky Mental Health Manpower Commission, Louisville, which is supported by contract 43-63-1152 from the National Institute of Mental Health, Public Health Service. This paper is based on the commission's July 1964. report, "A Recruitment Study of Nurses Registered as Inactive in Kentucky."
United States maintain their registration but are currently inactive (4).

A source of recruitment which had not been explored fully was that of the large number of nurses registered in Kentucky as inactive. According to unpublished 1963 data of the Kentucky State Board of Nursing Education and Nurse Registration, 29.3 percent $(2,271)$ of the nurses registered in the State were inactive. Of these nurses, 58 percent lived within commuting distance of a State mental hospital or school for the retarded; others lived close to community mental health centers.

Consequently, the Kentucky Mental Health Manpower Commission conducted a study to gather data on the inactive nurses' family status, educational history, work record, and other factors which might influence their return to nursing or their entry into psychiatric nursing, or both. Specifically, the study was designed for the following three purposes.

1. To determine why nurses are currently inactive and the extent to which they may be expected to return to full-time or part-time nursing employment.

2. To find new methods to ease the shortage of nurses in mental institutions (refresher courses, convenient work schedules, part-time employment, economic incentives).

3. To supply mental health facilities with the names of nurses who may be interested in returning to nursing and who have expressed interest in psychiatric nursing.

\section{Survey Method and Response}

A task force of representatives from the following associations and organizations was established to advise and assist the study: Kentucky Board of Nursing Education and Nurse 
Registration, Kentucky Department of Mental Health, Kentucky League for Nursing, Kentucky State Association of Registered Nurses, and the University of Kentucky College of Nursing.

A questionnaire, with a covering letter, was pretested with a 10 percent sample of the registered inactive nurses. A followup questionnaire and letter and a third letter were sent to pretest respondents to ascertain the value of more than one followup to the original request. In October 1963 questionnaires were sent to the remaining nurses registered as inactive. Newspaper releases, television, and a followup letter and questionnaire were used in the major survey.

The total survey, conducted in October 1963, contacted 2,271 nurses registered as inactive. These nurses represented approximately onethird of the total number of nurses registered in Kentucky. Eighty-two percent of the nurses responded. Of the 1,866 respondents, 15 percent indicated that they were currently employed, either full time or part time, as nurses; 32 percent definitely planned to return to nursing; 26 percent were uncertain about future plans; and 21 percent did not plan to return. About 6 percent of the returned questionnaires were discarded because either the nurses no longer lived in the State or the answers were inadequate.

These percentages make possible some interesting and important conclusions. First, that 15 percent of the respondents are now employed in nursing indicates that a large number of inactive nurses do return to the profession. Second, that 32 percent of the respondents definitely plan to return means that more than one of every four inactive nurses in Kentucky intends to re-enter the field. One in four is probably a conservative figure when the 26 percent of the uncertain respondents is considered; presumably, some of those who are uncertain will return.

With a potential recruitment source of approximately 1,100 nurses, health and particularly mental health leaders who need nurses may be interested in the following information about nurses who might be recruited.

\section{Family and Personal Data}

Items of personal history, such as age, marital status, husband's occupation, number of children at home, age of youngest child, and reasons for current inactivity, were studied for significant factors relative to inactivity as opposed to activity.

The respondents definitely planning to return, those who are uncertain, those not planning to return, and those currently employed in nursing are shown by age groups in table 1 . In addition, data for 1962 from the 1964 edition of "Facts About Nursing," published by the American Nurses' Association, on employed registered nurses in Kentucky and the United States are shown for comparison. The most outstanding differences occur in the two

Table 1. Career plans of inactive nurses in Kentucky, 1963, and percentage of employed nurses in Kentucky and the United States, 1962, by age groups

\begin{tabular}{|c|c|c|c|c|c|c|c|c|c|c|}
\hline \multirow{2}{*}{$\underset{\text { (years) }}{\text { Age group }}$} & \multicolumn{2}{|c|}{ Not returning } & \multicolumn{2}{|c|}{ Uncertain } & \multicolumn{2}{|c|}{ Returning } & \multicolumn{2}{|c|}{ Re-employed } & \multicolumn{2}{|c|}{$\begin{array}{c}\text { Percent } \\
\text { employed } 1\end{array}$} \\
\hline & $\underset{\text { ber }}{\text { Num- }}$ & Percent & Num- & Percent & $\underset{\text { ber }}{\text { Num- }}$ & Percent & $\underset{\text { ber }}{\text { Num- }}$ & Percent & $\begin{array}{l}\text { Ken- } \\
\text { tucky }\end{array}$ & $\begin{array}{l}\text { United } \\
\text { States }\end{array}$ \\
\hline $\begin{array}{l}20-29 \\
30-39 \\
40-49 \\
50-59 \\
60 \text { and over } \\
\text { Unknown }\end{array}$ & $\begin{array}{r}10 \\
81 \\
74 \\
88 \\
132 \\
11\end{array}$ & $\begin{array}{r}2.5 \\
20.4 \\
18.7 \\
22.2 \\
33.3 \\
2.8\end{array}$ & $\begin{array}{r}41 \\
168 \\
118 \\
113 \\
45 \\
\cdot 7\end{array}$ & $\begin{array}{r}\text { 8. } 3 \\
34.1 \\
24.0 \\
23.0 \\
9.1 \\
1.4\end{array}$ & $\begin{array}{r}129 \\
306 \\
100 \\
44 \\
12 \\
3\end{array}$ & $\begin{array}{r}21.7 \\
51.5 \\
16.8 \\
7.4 \\
2.0 \\
.5\end{array}$ & $\begin{array}{r}94 \\
80 \\
51 \\
29 \\
6 \\
27\end{array}$ & $\begin{array}{r}32.8 \\
27.9 \\
17.7 \\
10.1 \\
2.1 \\
9.4\end{array}$ & $\begin{array}{r}26.7 \\
25.6 \\
23.0 \\
17.3 \\
6.0 \\
1.4\end{array}$ & $\begin{array}{r}24.9 \\
24.5 \\
22.8 \\
17.7 \\
7.1 \\
3.0\end{array}$ \\
\hline Total_ & 396 & 100.0 & 492 & 100.0 & 594 & 100.0 & 287 & 100.0 & 100.0 & 100.0 \\
\hline
\end{tabular}

1 Reported by American Nurses' Association. 
younger and the two older age groups. The high percentage of nurses aged from 30 to 39 years who plan to return reflects a relatively recent inactivity because of marriage and families. The larger number of nurses over 50 years of age not planning to return reflects those who initially retired for family reasons and did not return or who had to retire because of poor health or age, or both. The age patterns indicate that return to nursing becomes less likely after age 50 .

The marital status and career plans of respondents and similar information on employed nurses in Kentucky and the United States are shown in table 2. Although marriage alone may not be sufficient cause for a nurse to leave the field, it seems logical that certain other factors which accompany marriage, such as the socioeconomic status of the family owing to the husband's occupation, number of children, and age of the youngest child, could influence career plans.

Table 3 gives some insights on the relationship of the occupation of a nurse's husband to her career plans. The occupations were classified according to Hollingshead's index of social position with one minor exception (5). Farmers in Hollingshead's scale are ranked according to the value of the farm owned and consequently are scattered over all ranks. Because

Table 2. Career plans of inactive nurses in Kentucky, 1963, and percentage of employed nurses in Kentucky and the United States, 1962, by marital status

\begin{tabular}{|c|c|c|c|c|c|c|c|c|c|c|}
\hline \multirow{2}{*}{ Marital status } & \multicolumn{2}{|c|}{ Not returning } & \multicolumn{2}{|c|}{ Uncertain } & \multicolumn{2}{|c|}{ Returning } & \multicolumn{2}{|c|}{ Re-employed } & \multicolumn{2}{|c|}{$\begin{array}{c}\text { Percent } \\
\text { employed }\end{array}$} \\
\hline & $\underset{\text { ber }}{\text { Num- }}$ & $\begin{array}{l}\text { Per- } \\
\text { cent }\end{array}$ & $\underset{\text { ber }}{\text { Num- }}$ & $\begin{array}{l}\text { Per- } \\
\text { cent }\end{array}$ & $\underset{\text { ber }}{\text { Num- }}$ & $\begin{array}{l}\text { Per- } \\
\text { cent }\end{array}$ & $\underset{\text { ber }}{\text { Num- }}$ & $\begin{array}{l}\text { Per- } \\
\text { cent }\end{array}$ & $\begin{array}{l}\text { Ken- } \\
\text { tucky }\end{array}$ & $\begin{array}{l}\text { United } \\
\text { States }\end{array}$ \\
\hline $\begin{array}{l}\text { Single } \\
\text { Married. } \\
\text { Other } \\
\text { Unknown }\end{array}$ & $\begin{array}{r}47 \\
288 \\
54 \\
7\end{array}$ & $\begin{array}{r}11.9 \\
72.7 \\
13.6 \\
1.8\end{array}$ & $\begin{array}{r}18 \\
442 \\
30 \\
2\end{array}$ & $\begin{array}{r}3.7 \\
89.8 \\
6.1 \\
.4\end{array}$ & $\begin{array}{r}5 \\
568 \\
21 \\
0\end{array}$ & $\begin{array}{r}0.9 \\
95.6 \\
3.5 \\
0\end{array}$ & $\begin{array}{r}14 \\
233 \\
15 \\
25\end{array}$ & $\begin{array}{r}4.9 \\
81.2 \\
5.2 \\
8.7\end{array}$ & $\begin{array}{r}24.8 \\
62.2 \\
9.2 \\
2.6\end{array}$ & $\begin{array}{r}25.6 \\
61.0 \\
11.0 \\
2.4\end{array}$ \\
\hline Total & 396 & 100.0 & 492 & 100.0 & 594 & 100.0 & 287 & 100.0 & 100.0 & 100.0 \\
\hline
\end{tabular}

1 Reported by American Nurses' Association.

Table 3. Career plans of inactive married nurses in Kentucky, 1963, by occupations of husbands

\begin{tabular}{|c|c|c|c|c|c|c|c|c|c|}
\hline \multirow{2}{*}{ Husbands' occupations } & \multirow{2}{*}{$\begin{array}{l}\text { Total } \\
\text { nurses }\end{array}$} & \multicolumn{2}{|c|}{ Not returning } & \multicolumn{2}{|c|}{ Uncertain } & \multicolumn{2}{|c|}{ Returning } & \multicolumn{2}{|c|}{ Re-employed } \\
\hline & & Number & Percent & Number & Percent & Number & Percent & Number & Percent \\
\hline $\begin{array}{l}\text { Physicians } \\
\text { Other major professio }\end{array}$ & 139 & 51 & 36.6 & 47 & 33. 9 & 32 & 23. 0 & 9 & 6.5 \\
\hline $\begin{array}{l}\text { and executives } \\
\text { Lesser professionals and }\end{array}$ & 181 & 25 & 13. 8 & 57 & 31.5 & 77 & 42.5 & 22 & 12. 2 \\
\hline business managers & 204 & 38 & 18. 6 & 55 & 26. 9 & 81 & 39. 7 & 30 & 14.8 \\
\hline $\begin{array}{l}\text { Minor proresinionals and } \\
\text { admintrative persons } \\
\text { Clerical, sales, technical -..- } \\
\text { Machled manual employees. }\end{array}$ & $\begin{array}{l}342 \\
133 \\
191\end{array}$ & $\begin{array}{l}51 \\
21 \\
15\end{array}$ & $\begin{aligned} 14.9 \\
15.7 \\
7.8\end{aligned}$ & $\begin{array}{r}104 \\
32 \\
49\end{array}$ & $\begin{array}{l}30.4 \\
24.1 \\
25.7\end{array}$ & $\begin{array}{r}129 \\
52 \\
82\end{array}$ & $\begin{array}{l}37.7 \\
39.1 \\
42.9\end{array}$ & $\begin{array}{l}58 \\
28 \\
45\end{array}$ & $\begin{array}{l}\text { 17. } 0 \\
\text { 21. } 1 \\
\text { 23. } 6\end{array}$ \\
\hline $\begin{array}{l}\quad \text { semiskilled employees } \\
\text { Unskilled labor } \\
\text { Farmers } \\
\text { Unknown }\end{array}$ & $\begin{array}{r}38 \\
3 \\
49 \\
251\end{array}$ & $\begin{array}{r}4 \\
0 \\
14 \\
69\end{array}$ & $\begin{array}{l}10.5 \\
0 \\
28.5 \\
27.4\end{array}$ & $\begin{array}{r}9 \\
1 \\
13 \\
75\end{array}$ & $\begin{array}{l}23.7 \\
33.3 \\
26.6 \\
29.9\end{array}$ & $\begin{array}{r}19 \\
2 \\
17 \\
77\end{array}$ & $\begin{array}{l}50.0 \\
66.7 \\
34.6 \\
30.7\end{array}$ & $\begin{array}{r}6 \\
0 \\
5 \\
30\end{array}$ & $\begin{array}{l}15.8 \\
0 \\
10.3 \\
12.0\end{array}$ \\
\hline Total_... & 1,531 & 288 & 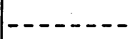 & 442 & 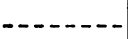 & 568 & $\ldots$ & 233 & \\
\hline
\end{tabular}


there was no property value clue in the collected data, farmers were grouped into one separate class. Because of the relatively small percentage of nurses in the survey who were married to farmers, no significant distortion of the proportions in other classes existed.

Perhaps the most striking example of the effect of a husband's occupation on his wife's plans to return to nursing is that of the nurses who are married to physicians. The data indicate that marriage to a physician enhances the probability that the nurse will remain inactive. This is true to a greater degree than marriage to other professionals and executives on the same socioeconomic scale. The other most noticeable differences occur in the minor professionals and clerical and skilled groups, where the proportion of nurses who have returned or are planning to return is greater than among those married to major professionals. The income levels for most of the occupations in these groups are such that a working wife can contribute to the family income. By the same token, she is less likely to employ a helper in the home in order to participate in activities outside the home unless she is employed. Thus, it can be concluded that a husband's occupation does influence the nurse's plan to return to the field.

In addition to the career significance of marriage and the economic status relative to the husband's occupation, the presence and number of children at home was studied in relation to career plans. The presence of children in the home enhances the likelihood that a nurse will return to the field (table 4).

Table 5 shows the age of the youngest child at home and reveals a key difference between those who have returned or plan to return to nursing and those who do not intend to return. A considerable number of mothers who do not plan to return to nursing have children under

Table 4. Career plans of inactive nurses in Kentucky, 1963, who are or have been married, by number of children at home

\begin{tabular}{|c|c|c|c|c|c|c|c|c|c|}
\hline \multirow{2}{*}{ Number children } & \multirow{2}{*}{$\begin{array}{c}\text { Total } \\
\text { nurses }\end{array}$} & \multicolumn{2}{|c|}{ Not returning } & \multicolumn{2}{|c|}{ Uncertain } & \multicolumn{2}{|c|}{ Returning } & \multicolumn{2}{|c|}{ Re-employed } \\
\hline & & Number & Percent & Number & Percent & Number & Percent & Number & Percent \\
\hline $\begin{array}{l}\text { None. } \\
\text { 1 } \\
\text { 2 } \\
\text { 5 } \\
\text { 6r. more }\end{array}$ & $\begin{array}{r}402 \\
218 \\
411 \\
302 \\
165 \\
78 \\
61 \\
49\end{array}$ & $\begin{array}{r}165 \\
35 \\
50 \\
36 \\
28 \\
11 \\
13 \\
11\end{array}$ & $\begin{array}{l}41.0 \\
16.0 \\
12.1 \\
11.9 \\
16.9 \\
14.1 \\
21.3 \\
22.4\end{array}$ & $\begin{array}{r}142 \\
54 \\
93 \\
89 \\
42 \\
27 \\
17 \\
10\end{array}$ & $\begin{array}{l}35.3 \\
24.8 \\
22.6 \\
29.4 \\
25.5 \\
34.6 \\
27.8 \\
20.4\end{array}$ & $\begin{array}{r}55 \\
84 \\
186 \\
132 \\
75 \\
33 \\
22 \\
2\end{array}$ & $\begin{array}{r}13.7 \\
38.5 \\
45.3 \\
43.7 \\
45.4 \\
42.3 \\
36.1 \\
4.1\end{array}$ & $\begin{array}{r}40 \\
45 \\
82 \\
45 \\
20 \\
7 \\
9 \\
26\end{array}$ & $\begin{array}{r}10.0 \\
20.7 \\
20.0 \\
15.0 \\
12.2 \\
9.0 \\
14.8 \\
53.1 \\
\end{array}$ \\
\hline Total & 1,686 & 349 & $-\ldots \ldots$ & 474 & - $-\ldots$ & 589 & $-\cdots-$ & 273 & -1 \\
\hline
\end{tabular}

Table 5. Career plans of inactive nurses in Kentucky, 1963, by age of youngest child at home

\begin{tabular}{|c|c|c|c|c|c|c|c|c|c|}
\hline \multirow{2}{*}{$\begin{array}{l}\text { Age group of youngest } \\
\text { child (years) }\end{array}$} & \multirow{2}{*}{$\begin{array}{c}\text { Total } \\
\text { nurses }\end{array}$} & \multicolumn{2}{|c|}{ Not returning } & \multicolumn{2}{|c|}{ Uncertain } & \multicolumn{2}{|c|}{ Returning } & \multicolumn{2}{|c|}{ Re-employed } \\
\hline & & Number & Percent & Number & Percent & Number & Percent & Number & Percent \\
\hline $\begin{array}{l}\text { Under } 5 \\
\text { 5-9 } \\
10-14 \\
15-17 \\
\text { Un and over }\end{array}$ & $\begin{array}{r}729 \\
295 \\
\therefore \quad 171 \\
27 \\
9 \\
4\end{array}$ & $\begin{array}{r}66 \\
52 \\
48 \\
4 \\
3 \\
0\end{array}$ & $\begin{array}{r}9.0 \\
17.6 \\
28.0 \\
14.8 \\
33.3 \\
0\end{array}$ & $\begin{array}{r}164 \\
96 \\
\quad 47 \\
10 \\
4 \\
\quad 1\end{array}$ & $\begin{array}{l}22.5 \\
32.5 \\
27.5 \\
37.0 \\
44.4 \\
25.0\end{array}$ & $\begin{array}{r}359 \\
111 \\
51 \\
7 \\
1 \\
3\end{array}$ & $\begin{array}{l}49.2 \\
37.6 \\
29.8 \\
25.9 \\
11.1 \\
75.0\end{array}$ & $\begin{array}{r}140 \\
36 \\
25 \\
6 \\
1 \\
0\end{array}$ & $\begin{array}{l}19.3 \\
12.3 \\
14.7 \\
22.3 \\
11.2 \\
0\end{array}$ \\
\hline$\because$ Total & 1,235 & 173 & 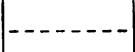 & 322 & $\ldots \ldots$ & 532 & $\ldots-\ldots$ & 208 & $-\ldots$ \\
\hline
\end{tabular}


high school age. Preschool-age children are a factor in current or recent inactivity among nurses and especially so if there are two or three children who probably are still very young.

An analysis of the primary reason which the nurses gave for their current status is presented in table 6. From a list of statements, presented in the same order as on the questionnaire, each nurse was asked to choose one reason which most specifically explained her current inactivity. In the pretest (the results of which are included), the reason, "believe that a mother should be at home with her children," was included. The task force consultant group which helped to guide the survey, however, felt that the high proportion who chose this reason on the pretest were giving a socially required answer rather than a realistic one, and this reason was not listed in the final survey. If a nurse, under the heading of "other reason," wrote in such a statement, it was coded as a specific reason.

Responses to the primary reason indicate the nurse who plans to return is not like her sister nurse who plans to remain inactive; she feels differently about her present situation and her future.

The nurses who do not plan to return have more personal health problems, which might be expected if for no other reason than because they are a slightly older group. But of most interest in terms of reactivating nurse manpower is the concern for care of small children among the nurses who do plan to return and even among those who are uncertain about future plans. The responses certainly indicated that nurses are conscious of husband and children; the top three reasons in all groups included the husband's preference that the wife not work and the nurse's preference for the homemaker role. There was, however, a difference in emphasis or importance indicated by the proportion in each group who cited these choices. The relative importance of salary, working hours, and reluctance because of inactivity are not to be overlooked as factors both for those who do plan to return as well as for those who are uncertain.

\section{Work Experience}

The recentness of acquired training and knowledge and the areas of special interest are important to prospective employers. Therefore, the data in this section present this information on the responding nurses as a means of

\section{Table 6. Career plans of inactive nurses in Kentucky, 1963, by reasons for inactivity}

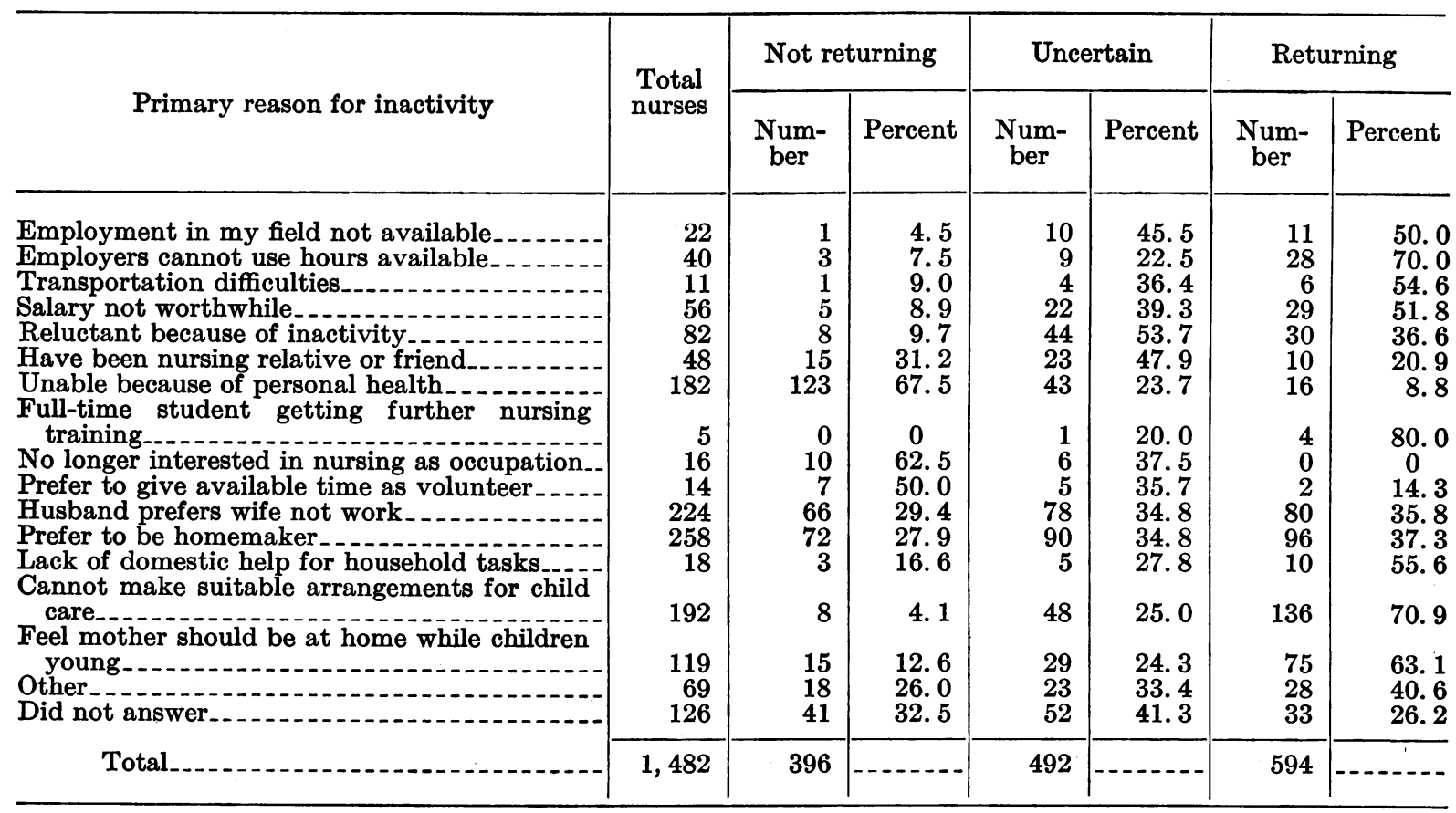


evaluating potential nurse manpower. The data on years of nursing experience and time since last employed as a nurse are given for those who are definitely planning to return and those who are uncertain as well as those who are not planning to return.

A majority of the nurses who plan to return have less than 10 years of experience (table 7), and 50 percent have been out of nursing less than 6 years (table 8). By contrast, only 17 percent of those who do not plan to return left the field this recently. This is an indication that those who do plan to return have had both their training and experience recently enough for them to still be familiar with relatively current nursing knowledge and practices.

\section{Future Plans and Preferences}

The data presented so far include nurses who plan to return to nursing as well as those who do not plan to return. The remainder of the data are concerned only with those who plan to return to nursing. Of primary interest are when these nurses plan to return, the workload they desire, and the kind of work they prefer.

Almost half of the respondents to the questionnaires gave no definite time for return or amount of work desired; but, from their responses, a fairly accurate guess could be based on the age of the youngest child at home and how long it will be before he is in school. Of

Table 7. Career plans of inactive nurses in Kentucky, 1963, by years of nursing experience

\begin{tabular}{|c|c|c|c|c|c|c|}
\hline \multirow{2}{*}{$\begin{array}{c}\text { Years of } \\
\text { experience }\end{array}$} & \multicolumn{2}{|c|}{ Not returning } & \multicolumn{2}{|c|}{ Uncertain } & \multicolumn{2}{|c|}{ Returning } \\
\hline & $\underset{\text { ber }}{\text { Num- }}$ & $\begin{array}{l}\text { Per- } \\
\text { cent }\end{array}$ & $\underset{\text { ber }}{\text { Num- }}$ & $\begin{array}{l}\text { Per- } \\
\text { cent }\end{array}$ & $\underset{\text { ber }}{\text { Num- }}$ & $\begin{array}{l}\text { Per- } \\
\text { cent }\end{array}$ \\
\hline $\begin{array}{l}\text { Less than } \\
1 \\
1-4 \\
5-9 \\
10-14 \\
15-19 \\
20 \text { and }\end{array}$ & $\begin{array}{r}6 \\
79 \\
71 \\
36 \\
22\end{array}$ & $\begin{array}{r}1.5 \\
20.0 \\
17.9 \\
9.1 \\
5.6\end{array}$ & $\begin{array}{r}2 \\
148 \\
147 \\
54 \\
24\end{array}$ & $\begin{array}{r}0.4 \\
30.1 \\
29.9 \\
11.0 \\
4.9\end{array}$ & $\begin{array}{r}4 \\
212 \\
222 \\
75 \\
29\end{array}$ & $\begin{array}{r}0.7 \\
35.7 \\
37.4 \\
12.6 \\
4.9\end{array}$ \\
\hline Unknown & $\begin{array}{r}76 \\
106\end{array}$ & $\begin{array}{l}19.2 \\
26.8\end{array}$ & $\begin{array}{l}48 \\
69\end{array}$ & $\begin{array}{r}9.8 \\
14.0\end{array}$ & $\begin{array}{l}24 \\
28\end{array}$ & $\begin{array}{l}\text { 4. } 0 \\
\text { 4. } 7\end{array}$ \\
\hline Total & 396 & 100.0 & 492 & 100. 0 & 594 & 100.0 \\
\hline
\end{tabular}

Table 8. Career plans of inactive nurses in Kentucky, 1963, by termination date of last nursing position

\begin{tabular}{|c|c|c|c|c|c|c|}
\hline \multirow{2}{*}{$\begin{array}{c}\text { Year of } \\
\text { termina- } \\
\text { tion }\end{array}$} & \multicolumn{2}{|c|}{ Not returning } & \multicolumn{2}{|c|}{ Uncertain } & \multicolumn{2}{|c|}{ Returning } \\
\hline & Num- $_{\text {ber }}$ & $\begin{array}{l}\text { Per- } \\
\text { cent }\end{array}$ & $\underset{\text { ber }}{\text { Num- }}$ & $\begin{array}{l}\text { Per- } \\
\text { cent }\end{array}$ & $\underset{\text { ber }}{\text { Num- }}$ & $\begin{array}{l}\text { Per- } \\
\text { cent }\end{array}$ \\
\hline $\begin{array}{l}1963 \\
1962 \\
1961 \\
1960 \\
1959 \\
1954-58 \\
\text { Before }\end{array}$ & $\begin{array}{r}5 \\
16 \\
17 \\
16 \\
13 \\
73\end{array}$ & $\begin{array}{r}1.3 \\
4.0 \\
4.3 \\
4.0 \\
3.3 \\
18.4\end{array}$ & $\begin{array}{r}15 \\
24 \\
36 \\
24 \\
24 \\
112\end{array}$ & $\begin{array}{r}\text { 3. } 0 \\
4.9 \\
7.3 \\
\text { 4. } 9 \\
\text { 4. } 9 \\
22.8\end{array}$ & $\begin{array}{r}36 \\
61 \\
82 \\
69 \\
53 \\
153\end{array}$ & $\begin{array}{r}6.1 \\
10.3 \\
13.8 \\
11.6 \\
8.9 \\
25.8\end{array}$ \\
\hline $\begin{array}{c}\text { Betore } \\
1954 . . \\
\text { Unknown }\end{array}$ & $\begin{array}{r}160 \\
96\end{array}$ & $\begin{array}{l}40.4 \\
24.2\end{array}$ & $\begin{array}{r}165 \\
92\end{array}$ & $\begin{array}{l}33.5 \\
18.7\end{array}$ & $\begin{array}{r}100 \\
40\end{array}$ & $\begin{array}{r}16.8 \\
6.7\end{array}$ \\
\hline Total & 396 & 100.0 & 492 & 100.0 & 594 & 100.0 \\
\hline
\end{tabular}

those nurses who gave an estimated year of return, 82 percent indicated that they would return within 5 years.

For the employer who will consider part-time nurses, a ready source seems to be available, and the supply will grow steadily over the next 5 years, as indicated in table 9. Most of the nurses who expressed a specific preference for a desired workload indicated that they wanted part-time employment. In fact, four out of five nurses plan to return on a part-time basis. The questionnaires contained many voluntary comments about part-time work, ranging from the nurses' definitions of part time to criticisms of past experience with part-time employment. Many respondents indicated that they would like to work a few hours each day. Several commented on hospital practices which put the parttime nurse into a new situation or area each day she worked.

The fields of employment preferred by nurses planning to return are shown in table 10. Comparable data for currently employed nurses in Kentucky and the United States are also included. As shown in the table, the inactive nurses clearly prefer hospital nursing to private duty, which is usually full shift.

The preferred positions of inactive nurses planning to return, and the percentage employed in these positions in Kentucky and the United States are shown in table 11. The nurses who plan to return are realistically more interested in staff positions. This is related to 
Table 9. Estimated years until return to work by inactive nurses in Kentucky, 1963, by workload desired

\begin{tabular}{|c|c|c|c|c|c|c|c|c|c|c|c|c|}
\hline \multirow{3}{*}{ Workload desired } & \multicolumn{2}{|c|}{ Total nurses } & \multicolumn{10}{|c|}{ Indicated years until return to nursing } \\
\hline & \multirow{2}{*}{$\underset{\text { ber }}{\text { Num- }}$} & \multirow{2}{*}{$\begin{array}{l}\text { Per- } \\
\text { cent }\end{array}$} & \multicolumn{2}{|c|}{1} & \multicolumn{2}{|c|}{2} & \multicolumn{2}{|c|}{$3-5$} & \multicolumn{2}{|c|}{ More than 5} & \multicolumn{2}{|c|}{ Uncertain } \\
\hline & & & Num- $_{\text {ber }}$ & $\begin{array}{l}\text { Per- } \\
\text { cent }\end{array}$ & $\underset{\text { ber }}{\text { Num- }}$ & $\begin{array}{l}\text { Per- } \\
\text { cent }\end{array}$ & $\underset{\text { ber }}{\text { Num- }}$ & $\begin{array}{l}\text { Per- } \\
\text { cent }\end{array}$ & $\underset{\text { ber }}{\text { Num- }}$ & $\begin{array}{l}\text { Per- } \\
\text { cent }\end{array}$ & $\underset{\text { ber }}{\text { Num- }}$ & $\begin{array}{l}\text { Per- } \\
\text { cent }\end{array}$ \\
\hline $\begin{array}{l}\text { Full time- } \\
\text { Part time. } \\
\text { Undecided. }\end{array}$ & $\begin{array}{r}73 \\
270 \\
251\end{array}$ & $\begin{array}{l}12.3 \\
45.5 \\
42.2\end{array}$ & $\begin{array}{l}18 \\
49 \\
32\end{array}$ & $\mid$\begin{tabular}{l}
$-1-$ \\
\hdashline$--n$
\end{tabular} & $\begin{array}{l}11 \\
25 \\
11\end{array}$ & $\mid$\begin{tabular}{l}
$-\cdots-$ \\
\hdashline$-\cdots$
\end{tabular} & $\begin{array}{l}16 \\
59 \\
28\end{array}$ & 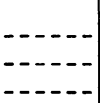 & $\begin{array}{r}6 \\
19 \\
28\end{array}$ & 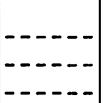 & $\begin{array}{r}22 \\
118 \\
152\end{array}$ & 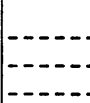 \\
\hline Total. & 594 & 100.0 & 99 & 16.7 & 47 & 7.9 & 103 & 17.3 & 53 & 8.9 & 292 & 49.2 \\
\hline
\end{tabular}

their desire for part-time employment and, because they realize that since they have been inactive for some time, they probably could not qualify for the higher level positions.

\section{Interest in Psychiatric Nursing}

Of special interest to those concerned with mental health facilities is the background of training and experience of nurses who plan to return to the field and who have an interest in psychiatric nursing. Accordingly, the re-

Table 10. Inactive nurses in Kentucky planning to return to work, 1963 , and percentage of employed nurses in Kentucky and the United States, 1962, by field of nursing

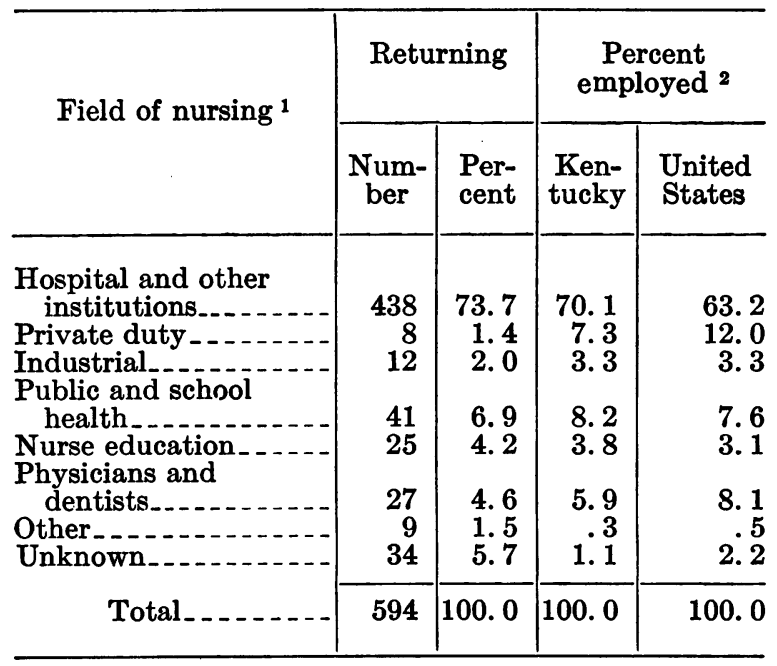

1 Indicated preference of inactive nurses.

2 Reported by American Nurses' Association.
Table 11. Inactive nurses in Kentucky planning to return to work, 1963, and percentage of employed nurses in Kentucky and the United States, 1962, by nursing position

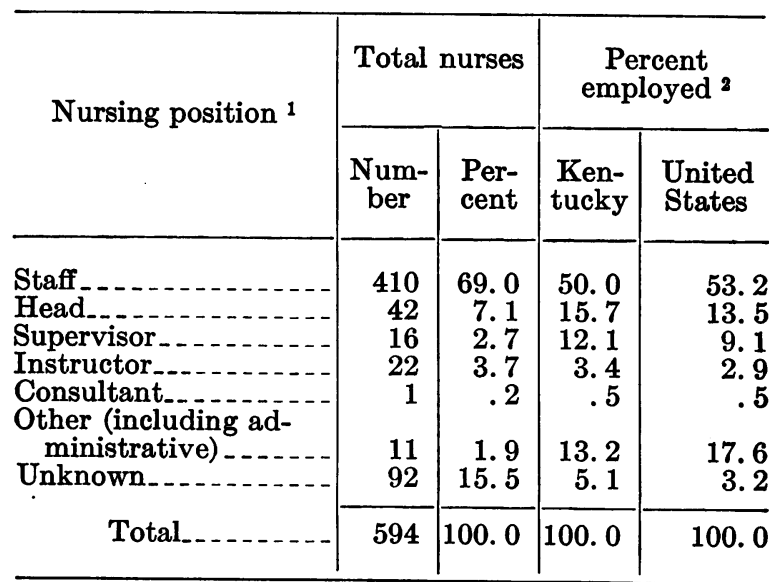

1 Indicated preference of inactive nurses.

2 Reported by American Nurses' Association.

spondents were asked to indicate whether they would be interested in working in a mental hospital or community mental health center in addition to other preferences they may have expressed earlier in the questionnaire.

The service preference of the 438 inactive nurses who indicated a desire for hospital nursing (table 10) and the percentage of nurses with previous psychiatric experience (beyond basic training) by the areas of their preference are shown in table 12. Ten percent prefer psychiatric nursing, and the factor of previous psychiatric experience has a slight positive influence on preference for psychiatric nursing. 
Of the 594 nurses who plan to return to work, 54 percent expressed interest in psychiatric work. To evaluate the effect of training on interest in mental health nursing, a tabulation was made of the presence or absence of formal psychiatric training or public health training or both, in relation to expression of interest. Either separately or in combination, formal training in these two areas does not seem to enhance the interest of a nurse in mental health work (table 13).

Of the 321 nurses who were interested, 64 percent had had one or both areas of training; but, this was also true for 63 percent of the 273

Table 12. Inactive nurses planning to return to hospital nursing and percentage with previous psychiatric experience, Kentucky, 1963, by preferred hospital service area

\begin{tabular}{|c|c|c|c|}
\hline \multirow{2}{*}{$\begin{array}{l}\text { Preferred hospital } \\
\text { service area }\end{array}$} & \multicolumn{2}{|c|}{ Total nurses } & \multirow{2}{*}{$\begin{array}{c}\text { Percent with } \\
\text { psychiatric } \\
\text { experience }\end{array}$} \\
\hline & Number & Percent & \\
\hline $\begin{array}{l}\text { Medical } \\
\text { Pediatric } \\
\text { Surgical } \\
\text { Psychiatric } \\
\text { Obstetrics-gyne- } \\
\text { cology } \\
\text { Other } \\
\text { Unknown }\end{array}$ & $\begin{array}{r}84 \\
23 \\
148 \\
45 \\
89 \\
19 \\
30\end{array}$ & $\begin{array}{r}19.2 \\
5.2 \\
33.8 \\
10.3 \\
20.3 \\
4.3 \\
6.8\end{array}$ & $\begin{array}{r}17.8 \\
8.7 \\
15.5 \\
64.4 \\
13.5 \\
31.6 \\
20.0\end{array}$ \\
\hline Total & 438 & 100.0 & -- \\
\hline
\end{tabular}

Table 13. Interest in mental health nursing by inactive nurses in Kentucky, 1963, by previous formal training in public health and psychiatric nursing

\begin{tabular}{|c|c|c|c|c|c|}
\hline \multirow{3}{*}{ Previous training } & \multicolumn{5}{|c|}{ Employment in mental health } \\
\hline & \multirow{2}{*}{$\begin{array}{c}\text { Total } \\
\text { nurses }\end{array}$} & \multicolumn{2}{|c|}{ Interested } & \multicolumn{2}{|c|}{ Not interested } \\
\hline & & $\underset{\text { ber }}{\text { Num- }}$ & $\begin{array}{l}\text { Per- } \\
\text { cent }\end{array}$ & $\underset{\text { ber }}{\text { Num- }}$ & $\begin{array}{l}\text { Per- } \\
\text { cent }\end{array}$ \\
\hline $\begin{array}{l}\text { Psychiatric only } \\
\text { Public health } \\
\text { only } \\
\text { Both } \\
\text { Neither } \\
\text { Unknown }\end{array}$ & $\begin{array}{r}181 \\
21 \\
177 \\
191 \\
24\end{array}$ & \begin{tabular}{r|}
102 \\
12 \\
93 \\
103 \\
11
\end{tabular} & $\begin{array}{l}56.4 \\
57.1 \\
52.5 \\
53.9 \\
45.8\end{array}$ & $\begin{array}{r}79 \\
9 \\
9 \\
84 \\
88 \\
13\end{array}$ & $\begin{array}{l}43.6 \\
42.8 \\
47.5 \\
46.1 \\
54.2\end{array}$ \\
\hline Total & 594 & 321 & 54.0 & 273 & 46.0 \\
\hline
\end{tabular}

who were not interested in employment in mental health facilities. The majority of the nurses had received their psychiatric or public health training during the basic hospital program, and perhaps this accounts for its lack of significance in relation to interest.

\section{Recommendations}

A considerable number of nurses currently registered as inactive plan to return to nursing employment, and many of these have expressed an interest in psychiatric nursing. We therefore recommend that consideration be given to the possibility of developing recruitment devices such as re-orientation courses, retraining programs, and refresher courses to acquaint inactive nurses with changes in psychiatric nursing. Perhaps many of the nurses who desire part-time work can be recruited into mental health facilities.

A major obstacle in recruitment and retention of many nurses is their difficulty in arranging for care of their children. Therefore, operation of a children's day-care center might be considered by administrators of mental health facilities.

Results of the survey indicate that the psychiatric training and experience which nurses receive is probably inadequate. As noted previously, past psychiatric training and experience seem to have little positive effect on the desire of inactive nurses to return to this field. Undoubtedly, both the facilities that train nurses and those who employ them should reexamine their programs.

Although not formally a part of the analysis, an examination of the questionnaires revealed a need for an improved program of public information and education to correctly inform the public, guidance counselors, and capable students of the demand for nurses, educational and training requirements of the profession, and particularly the rewards and satisfactions of nurse careers. Nursing organizations and associations, therefore, must improve methods of presenting the nursing profession to capable high school students. There is a particular need for such an educational program in psychiatric nursing.

These recommendations are offered as a basis for future action to solve some of the nursing 
needs of mental health facilities. Other actions have already been taken, based on the data from the study. The 1,086 nurses who indicated that they definitely planned to return to nursing or were uncertain about their future plans were contacted and informed of the current need for their services in health and particularly mental health facilities. They were asked if they had any objection to being referred to agencies who are recruiting. Of those contacted, $715 \mathrm{did}$ not object to being referred. An interest in either hospital or community psychiatric nursing had been expressed by 321 of the 715 .

Federal, State, and private psychiatric hospitals, community clinics, mental health centers, and other related facilities were notified that lists were available of nurses in their area who might be interested in returning to the field and who had expressed an interest in psychiatric nursing. The names of 129 nurses who reside within commuting distance of a mental health facility were referred to appropriate nursing directors for recruitment. At last report, a continuous effort was being made to recruit from the lists of nurses, and two of the facilities reported limited success.

The recommendation for a children's daycare center as a recruitment-retention device has been formally made to the Kentucky Department of Mental Health. Also, we are working with two of the State mental hospitals which are in the process of establishing such a program.

\section{Summary}

In a 1963 study of nurses registered as inactive in Kentucky, the Kentucky Mental Health Manpower Commission used a question- naire and followup survey to obtain data on the nurses' family status, educational history, work record, and other related factors. The study's purpose was to determine why nurses are inactive, the extent to which they may be expected to return to nursing employment, and to seek new methods to ease the shortage of nurses in mental health facilities.

Results of the study revealed that approximately one of every two inactive nurses who maintain their registration in Kentucky may eventually return to nursing. Generally, the nurse who will re-enter the field is under 50 years of age, has one to three children, and has received her training fairly recently. The nurse who plans to return prefers a part-time staff position in a hospital setting. Previous psychiatric work experience or formal psychiatric training seems to have little effect on the selection of psychiatric nursing as a specialty. Lack of available care for children is a major obstacle to the nurses' re-entry into the field.

\section{REFERENCES}

(1) Surgeon General's Consultant Group on Nursing: Report. Toward quality in nursing. PHS Publication No. 992. U.S. Government Printing Office, Washington, D.C., 1963.

(2) American Psychiatric Association: Psychiatric studies and project. No. 10. Washington, D.C., September 1963.

(3) Kentucky Mental Health Manpower Commission: Mental health manpower. Louisville, Ky., 1962.

(4) American Nurses' Association. Facts about nursing. New York, 1964.

(5) Hollingshead, A. B.: Two factor index of social position. Mimeographed. New Haven, Conn., 1957. 


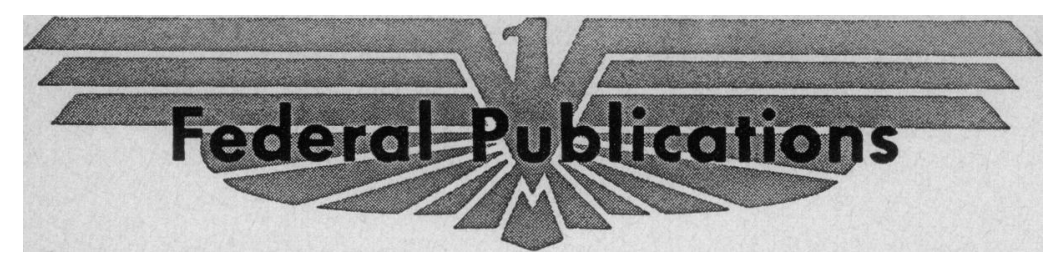

Emergency Health Service Preparedness Check List. PHS Publication No. 1071-A-3; 1965; 4 pages. Contains a brief discussion of community emergency health service programs and a checklist of 17 questions which may be answered "yes" or "no." The checklist is designed for use by State and local health and civil defense officials and community leaders responsible for preparing emergency health service preparedness plans. List will aid in evaluating progress made in the preparation of plans and will be helpful in followup surveys.

Nurse Training Act of 1964. $P H S$ Publication No. 1154; March 1965; 12 pages. One of a series of six publications on the Nurse Training Act briefly summarizing the act. Each of the other five pamphlets in the series deals with a single provision of the act: Professional Nurse Traineeship Program, PHS Publication No. 1154-1; Project Grants for Improvement in Nurse Training, PHS Publication No. 1154-2 ; Payments to Diploma Schools of Nursing, PHS Publication No. 1154-3; Nursing Student Loan Program, PHS Publication No. 1154-4; and Construction Grants Program for Schools of Nursing, PHS Publication No. 1154-5.

A Child-Centered Program to Prevent Tuberculosis. PHS Publication No. 1280; 1965 ; 41 pages; 25 cents. Designed to provide health departments, school health officials, and others who work with children with the specific procedures that are needed to organize and conduct a child-centered program to prevent tuberculosis. Discusses individuals who will need services, what services will be needed, the groups that can assist, what must be decided, and what must be done for individuals concerned if the program is to be effective. Also includes $a$ step-by-step discussion of tuberculin testing, sample forms and letters, and a discussion of how to distinguish these persons who are infected with tubercle bacilli from those who are not.

Manual for Protection of Public Water Supplies From Chemical Agents. PHS Publication No. 1071$J-1 ; 1965$; 30 pages. Describes potential hazard from chemical agents to public water supplies either by accidental or deliberate means. Details preventive measures, determination tests, treatment procedures, and tolerance limits. Outlines tests from "Standard Methods for the Examination of Water, Sewage, and Industrial Wastes." Manual should serve as an authoritative reference as well as an aid in training auxiliary personnel to serve in all types of disasters.

A Comparative Study of 40 Nursing Homes. Their design and use. PHS Publication No. 930-D-17; by A. Rorke Vanston, Leslie M. Abbe, and Maury Hampton; March 1965; 26 pages; 25 cents. Summarizes findings of a study of 20 proprietary homes and 20 homes constructed with Federal aid under the Hill-Burton Hospital and Medical Facilities Construction program. Discusses patient characteristics, architectural considerations, and construction costs.

Hospital Personnel: Report of a personnel research project. $P H S$ Publication No. 930-C-9; October 1964; 123 pages; 75 cents. Summarizes the findings of a research project carried out by St. Vincent's Hospital in New York City with funds provided by a research grant from the Public Health Service un- der the Hill-Burton program. Provides guidelines on the role of personnel in efficient hospital management, financial stability, and quality of patient care. Discusses the objectives and methodology of the project and devotes a chapter to each of the following subjects: analysis of personnel turnover; the wage and salary program; recruitment, selection, personnel training, and management development; role of supervision; morale of nonsupervisory employees; and the reduction of status tensions of nurses' aides. In evaluating the project, the administrator of St. Vincent's Hospital indicated that the study had demonstrated that better patient care without increased hospital costs can be achieved through personnel practices that improve employee job satisfaction and performance.

Facts About the National Library of Medicine. PHS Publication No. 1277; 1965 ; 8 pages; 15 cents. Outlines the mission, history, organization, functions, and services of the National Library of Medicine. Describes the Library's collection and interlibrary loan program. Discusses MEDLARS, the library's computer-based Medical Literature Analysis and Retrieval System. Reviews the Library's intramural and extramural programs. Lists key publications produced or supported by the Library and tells how they may be obtained.

This section carries announcements of new publications prepared by the Public Health Service and of selected publications prepared with Federal support.

Unless otherwise indicated, publications for which prices are quoted are for sale by the Superintendent of Documents, U.S. Government Printing Office, Washington D.C., 20402. Orders should be accompanied by cash, check, or money order and should fully indentify the publication. Public Health Service publications which do not carry price quotations, as well as single sample copies of those for which prices are shown, can be obtained without charge from the Public Inquiries Branch, Public Health Service, Washington, D.C., 20201.

The Public Health Service does not supply publications other than its own. 